\title{
Hydrodynamic modeling of tsunamis from the Currituck landslide
}

\author{
Eric L. Geist ${ }^{\mathrm{a}, *}$, Patrick J. Lynett ${ }^{\mathrm{b}}$, Jason D. Chaytor ${ }^{\mathrm{c}}$ \\ a U.S. Geological Survey, 345 Middlefield Rd., MS 999, Menlo Park, CA 94025, USA \\ b Department of Civil Engineering, Texas AEM University, College Station, Texas, USA \\ c Woods Hole Oceanographic Institution, Woods Hole, Massachusetts, USA
}

\section{A R T I C L E I N F O}

Article history:

Accepted 24 September 2008

\section{Keywords:}

tsunami

landslide

hydrodynamic

runup

numerical model

sensitivity analysis

\begin{abstract}
A B S T R A C T
Tsunami generation from the Currituck landslide offshore North Carolina and propagation of waves toward the U.S. coastline are modeled based on recent geotechnical analysis of slide movement. A long and intermediate wave modeling package (COULWAVE) based on the non-linear Boussinesq equations are used to simulate the tsunami. This model includes procedures to incorporate bottom friction, wave breaking, and overland flow during runup. Potential tsunamis generated from the Currituck landslide are analyzed using four approaches: (1) tsunami wave history is calculated from several different scenarios indicated by geotechnical stability and mobility analyses; (2) a sensitivity analysis is conducted to determine the effects of both landslide failure duration during generation and bottom friction along the continental shelf during propagation; (3) wave history is calculated over a regional area to determine the propagation of energy oblique to the slide axis; and (4) a high-resolution 1D model is developed to accurately model wave breaking and the combined influence of nonlinearity and dispersion during nearshore propagation and runup. The primary source parameter that affects tsunami severity for this case study is landslide volume, with failure duration having a secondary influence. Bottom friction during propagation across the continental shelf has a strong influence on the attenuation of the tsunami during propagation. The high-resolution 1D model also indicates that the tsunami undergoes nonlinear fission prior to wave breaking, generating independent, short-period waves. Wave breaking occurs approximately $40-50 \mathrm{~km}$ offshore where a tsunami bore is formed that persists during runup. These analyses illustrate the complex nature of landslide tsunamis, necessitating the use of detailed landslide stability/mobility models and higher-order hydrodynamic models to determine their hazard.
\end{abstract}

Published by Elsevier B.V.

\section{Introduction}

Potential sources for tsunamis affecting the east coast of the U.S. include submarine landslides that have been identified along the North American continental slope (Chaytor et al., 2009-this issue; Twichell et al., 2009-this issue). The occurrence of potentially tsunamigenic landslides off North America is infrequent, with return times measured in thousands of years and possibly waning with time since the last glacial/deglaciation period (Lee, 2009-this volume). Landslide tsunami hazards are still a present-day threat, however, as evidenced by the 1929 Grand Banks landslide tsunami (Fine et al., 2005). To assess the severity of this hazard along the U.S. Atlantic coast, we model the generation, propagation, and runup from tsunamis triggered by the Currituck landslide, one of the largest landslides along the North American Atlantic offshore margin. The headwall of the landslide is located approximately $100 \mathrm{~km}$ offshore North Carolina and Virginia, just down slope from the continental shelf edge. The morphology, stability, and dynamics of the slide have

\footnotetext{
* Corresponding author. Tel.: +1 650329 5457; fax: +1 6503295411.

E-mail address: egeist@usgs.gov (E.L. Geist).
}

been studied by Prior et al. (1986) and by studies presented in this volume (Locat et al., 2009-this issue; Twichell et al., 2009-this issue). The Currituck landslide complex is thought to be composed of at least two separate events, although the mobility analysis presented by Locat et al. (2009-this issue) suggest that these events occurred contemporaneously. Locat et al. (2009-this issue) also suggests that the landslide was triggered by a sudden increase in pore pressure, most likely from an earthquake. The geologic age of the landslide complex is 25-50 ka, occurring at a sea-level low stand (Lee, 2009-this issue). Although the Currituck landslide occurred thousands of years ago under different sea-level conditions, we can use the detailed analysis of this landslide to assess the range of potential, present-day tsunamis emanating from this type of source.

Previous studies of landslide-generated tsunamis uncovered distinct differences compared to earthquake-generated tsunamis (Lynett and Liu, 2002; Trifunac and Todorovska, 2002; Okal and Synolakis, 2004). Because of their smaller source dimensions, tsunamis from landslide sources are more affected by frequency dispersion (cf., Carrier, 1971). During open-ocean propagation, this will result in a long-wavelength leading wave with a higher-frequency wave train trailing behind. In addition, because of the large vertical displacements at the source in comparison to earthquake sources, hydrodynamic 
nonlinearity also becomes a significant factor in understanding the wave evolution for landslide tsunamis in the near field. Both of these factors, as well as the potential for wave breaking, become increasingly important as tsunami waves approach and runup onshore.

With regard to landslide dynamics, it is well known that speed of the failed mass is linked to the amplitude of the out-going wave (i.e., the wave propagating in the direction of slide movement) (e.g., Ward, 2001; Trifunac et al., 2002) as well as the initial acceleration, slide length and thickness, and whether the slide fails retrogressively (Haugen et al., 2005; Løvholt et al., 2005). The closer the landslide speed is to the phase speed of tsunamis $(c)$, given in the longwavelength limit by $c=\sqrt{g h}$ where $g$ is the gravitational acceleration and $h$ is the water depth, the higher the out-going tsunami amplitude. Even though a strong directivity is associated with the outgoing tsunami, the back-going tsunami propagating toward the near shore is the part of the wavefield that is potentially more dangerous, because of the shorter propagation distances (for a typical continental margin setting; fjords are a notable exception), and this is the part of the wavefield we focus on in this paper. Because the back-going tsunami quickly leaves the source region and is not "tuned" by seafloor movement in the slide direction, it is more complexly related to initial displacement of the slide mass immediately after failure. In the past, a poor understanding of submarine landslide dynamics, in combination with the higher-order hydrodynamic theory needed to model dispersion and nonlinearity, have been major obstacles in understanding landslide tsunamis. Recent research, however, has resulted in new modeling methods to address both of these problems (e.g., Imran et al., 2001; Lynett and Liu, 2002; Elverhøi et al., 2005; Lastras et al., 2005) that will undoubtedly lead to accelerated progress in estimating the severity of this natural hazard.

(a)

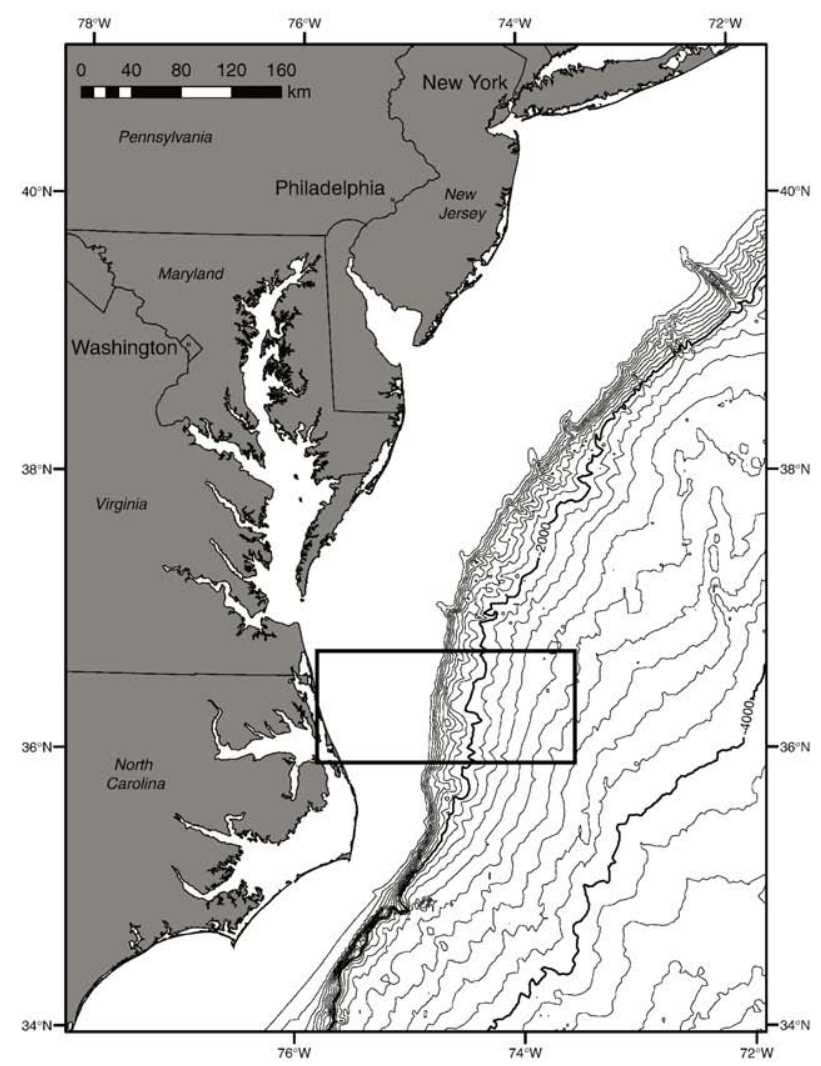

(b)

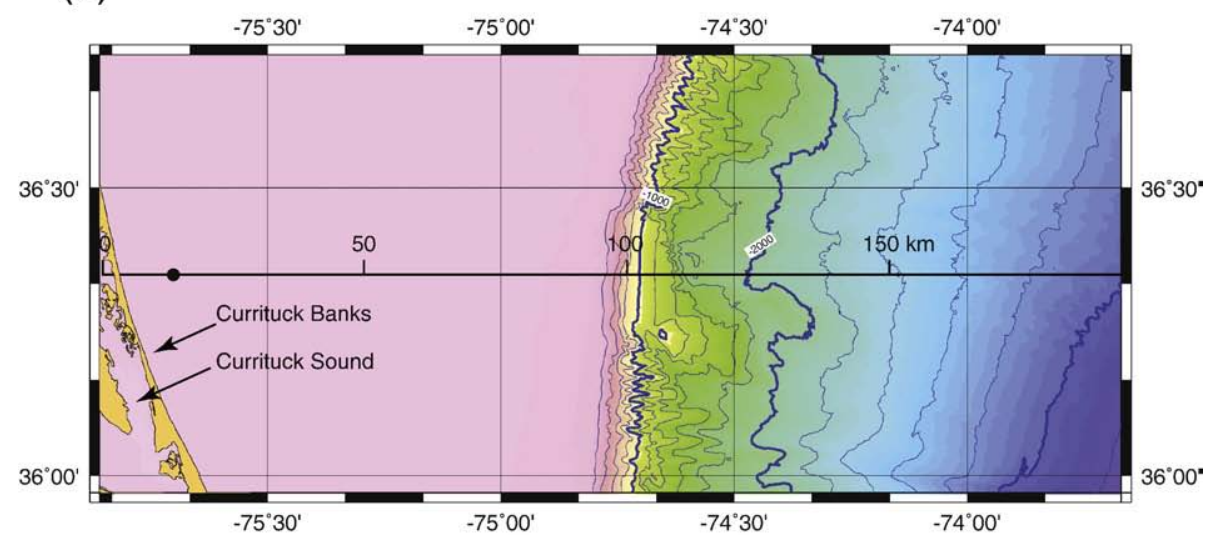

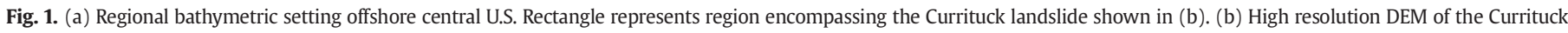

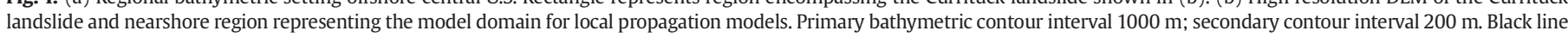

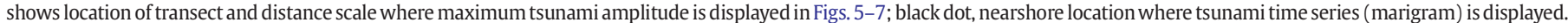


Finally, the broad continental shelf also has a significant effect on the wave evolution of tsunamis (Shibata, 1983), particularly those generated from continental slope landslides. Korycansky and Lynett $(2005,2007)$ indicate that shallow slopes associated with continental shelves will have a marked effect on large amplitude tsunamis, such as those from asteroid impacts, through attenuation from bottom friction and wave breaking far offshore (see also Glimsdal et al., 2007). One of the primary objectives in this study is to determine whether bottom friction and wave breaking are also important factors to determine the wave evolution of tsunamis generated by continental slope landslides during propagation across the continental shelf. It should be noted that the continental shelf shoreward of the Currituck landslide is one of the narrowest along the U.S. Atlantic margin (Fig. 1). The coastal region directly across (broadside) from the Currituck landslide is characterized by barrier islands (Currituck Banks) approximately 2-4 $\mathrm{m}$ in elevation and a back bay (Currituck Sound).

\section{Method}

\subsection{Bathymetry}

Multiple sources of data were used to build a digital elevation model (DEM) and the bathymetric grid for tsunami propagation and runup modeling (Fig. 1). These include data on the continental slope from NOAA Exclusive Economic Zone (EEZ) and University of New Hampshire Law of the Sea multibeam surveys (Gardner et al., 2006) and data on the continental shelf and in the nearshore regions extracted from the NOAA National Ocean Service (NOS) hydrographic and USGS Outer Banks survey databases. Topography data for the Currituck Banks area were extracted from the Shuttle Radar Topography Mission (SRTM) finished 3-arc second ( $90 \mathrm{~m}$ resolution) dataset. The areal extent of the grid encompasses the region downslope of the Currituck landslide as well as the coastal region broadside (directly across from) the landslide (Fig. 1b). Bathymetric and topographic data were gridded at a pixel/cell resolution of $200 \mathrm{~m}$ with the MB-System package (Caress and Chayes, 1996), employing a weighted average gridding scheme and with empty cells filled via a 2D thin-plate spline.

A $200 \mathrm{~m}$ uniform grid spacing is used for the source sensitivity studies, whereas a much finer grid spacing is used to model nearshore propagation and runup. An additional DEM, also at a resolution of $200 \mathrm{~m}$, was created to investigate the effects of a Currituck landslide tsunami over a wider section of the U.S. Atlantic coast (Section 3.3). For this larger, regional DEM ( $40 \mathrm{~N}$ to $35 \mathrm{~N}$ ), the same datasets as used in the smaller Currituck DEM were used with the addition of multibeam data covering sections of the continental slope and shelf collected on numerous survey and transit legs of the research vessels Atlantis, Knorr, and Ewing.

\subsection{Hydrodynamic modeling}

The model used for this study is the Cornell University Long and Intermediate Wave Modeling package (COULWAVE) (Lynett and Liu, 2002). COULWAVE was developed to model the propagation and runup of long and intermediate length waves, using fully nonlinear and dispersive wave theory (i.e., the nonlinear Boussinesq equations) as described in a number of papers (Lynett and Liu, 2002; Lynett et al., 2002; Lynett and Liu, 2005; Lynett, 2006). Because this wavemodeling package is computationally intensive, there are also options to use different approximations, such as weakly nonlinear, linear, and nondispersive forms of the wave equations. On the basis of initial tests, the weakly nonlinear "extended" equations (termed WNL-EXT in Lynett and Liu, 2002) were used for the multiple simulations of the Currituck landslide tsunami, including local propagation from different landslide scenarios and sensitivity tests of key parameters.
The WNL-EXT form of the wave equations described by Lynett and Liu (2002) are derived from the fully nonlinear form by assuming that the wavelength is much greater than the water depth and that the wave amplitude and vertical seafloor displacement are much smaller than the water depth. Specifically, for the nondimensional parameters

$\varepsilon=\frac{a_{0}}{h_{0}}, \quad \mu=\frac{h_{0}}{\ell_{0}}, \quad \delta=\frac{\Delta h}{h_{0}}$,

where $a_{0}$ is a characteristic amplitude, $h_{0}$ characteristic water depth, $\ell_{0}$ characteristic slide length, and $\Delta h$ is the change in seafloor depth,

$O(\varepsilon)=O(\delta)=O\left(\mu^{2}\right)<<1$.

In addition, the conventional form of the linear dispersion relation is "extended" to an arbitrary depth (Nwogu, 1993; Chen and Liu, 1995) which improves the accuracy for modeling intermediate-depth waves.

These equations are numerically implemented using a finitedifference algorithm and an iterative, high-order predictor-corrector scheme (Wei et al., 1995; Lynett and Liu, 2002). The open-ocean boundaries accommodate radiation of wave energy through a sponge layer, whereas runup on land boundaries is accommodated using a moving-boundary algorithm (Lynett et al., 2002). The time step used in the finite-difference algorithm is chosen to ensure numerical stability and is always less than that required by the CourantFriedrichs-Lewy stability criterion. We also present the results of 1D modeling below using the fully nonlinear equations (FNL-EXT) and a much finer grid spacing $(\Delta x=5 \mathrm{~m})$ to determine the wave evolution over the continental shelf and during overland flow.

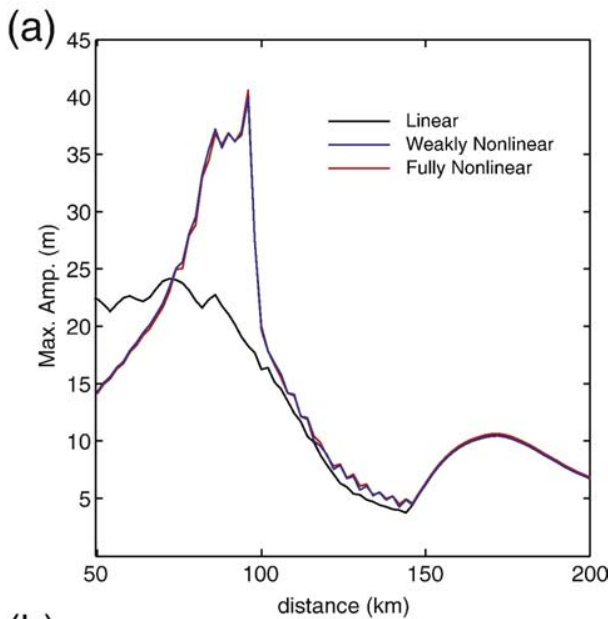

(b)

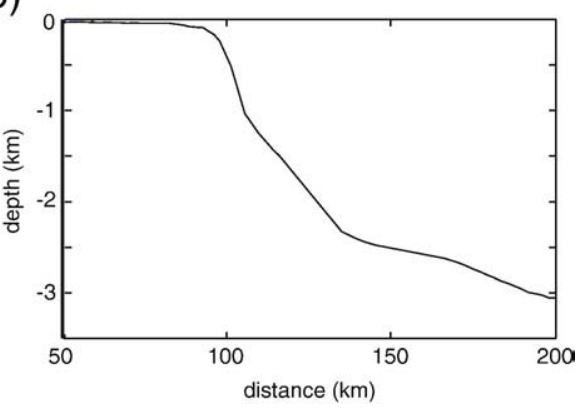

Fig. 2. (a) Comparison of maximum amplitude profiles aligned with slide axis for the linear, weakly nonlinear (WNL), and fully nonlinear (FNL) forms of the hydrodynamic equations. Simulation for highest amplitude composite slide (duration $=7.2 \mathrm{~min}$, $f=1.0 \times 10^{-3}$ ) using a coarse numeric grid. Nonlinear results using high-resolution grid presented in Fig. 12. (b) Bathymetric profile aligned with maximum amplitude profiles (See Fig. 1b). 


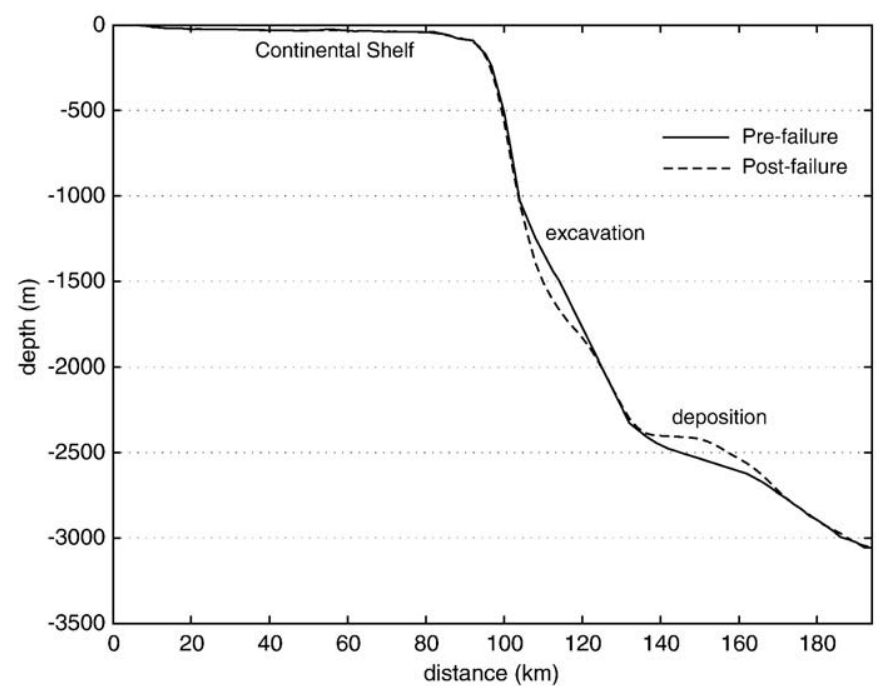

Fig. 3. Source used for generation of landslide tsunami. Initial displacement profile (solid line) compared to displacement profile of landslide after failure has occurred (dashed line).

The results of preliminary sensitivity tests on many of the parameters specified by COULWAVE (e.g., non-linearity, bottom friction, time and grid interval, energy dissipation from wave breaking) suggest that bottom friction and linear vs. nonlinear formulation have the greatest effect on the results. The linear assumption overestimates nearshore tsunami amplitudes for the Currituck landslide, in comparison to the more accurate nonlinear representations as shown in Fig. 2. In general, linear models that explicitly include slope, through a mild slope approximation for example, will tend to overestimate the shoaled wave height of a nonlinear wave, as compared to nonlinear model with similar
Table 1

Source parameters used in tsunami simulations and corresponding maximum runup broadside from the Currituck landslide.

\begin{tabular}{|c|c|c|c|c|}
\hline Slide scenario & $\frac{\text { Slide volume }}{\left(\mathrm{km}^{3}\right)}$ & $\frac{\text { Slide duration }}{(\min )}$ & $\begin{array}{l}\text { Bottom friction } \\
\text { coefficient }\end{array}$ & $\frac{\text { Runup }}{(\mathrm{m})}$ \\
\hline \multirow[t]{9}{*}{ Slide 1} & 108 & 7.2 & 0.001 & 6.10 \\
\hline & 108 & 10 & 0.001 & 5.70 \\
\hline & 108 & 20 & 0.001 & 4.20 \\
\hline & 108 & 7.2 & 0.0025 & 4.70 \\
\hline & 108 & 10 & 0.0025 & 4.30 \\
\hline & 108 & 20 & 0.0025 & 4.00 \\
\hline & 108 & 7.2 & 0.010 & 2.00 \\
\hline & 108 & 10 & 0.010 & 1.90 \\
\hline & 108 & 20 & 0.010 & 1.80 \\
\hline \multirow[t]{9}{*}{ Slide 2} & 57 & 7.2 & 0.001 & 3.67 \\
\hline & 57 & 10 & 0.001 & 3.00 \\
\hline & 57 & 20 & 0.001 & 2.40 \\
\hline & 57 & 7.2 & 0.0025 & 3.00 \\
\hline & 57 & 10 & 0.0025 & 3.00 \\
\hline & 57 & 20 & 0.0025 & 2.00 \\
\hline & 57 & 7.2 & 0.010 & 1.60 \\
\hline & 57 & 10 & 0.010 & 1.60 \\
\hline & 57 & 20 & 0.010 & 1.20 \\
\hline \multirow[t]{9}{*}{ Composite } & 165 & 7.2 & 0.001 & 8.80 \\
\hline & 165 & 10 & 0.001 & 8.00 \\
\hline & 165 & 20 & 0.001 & 6.10 \\
\hline & 165 & 7.2 & 0.0025 & 6.30 \\
\hline & 165 & 10 & 0.0025 & 5.80 \\
\hline & 165 & 20 & 0.0025 & 5.00 \\
\hline & 165 & 7.2 & 0.010 & 2.60 \\
\hline & 165 & 10 & 0.010 & 2.50 \\
\hline & 165 & 20 & 0.010 & 2.35 \\
\hline
\end{tabular}

Italics: Parameters used for scenario simulations.

assumptions (cf., Wei et al., 1995). In cases where slope is not explicitly included in propagation, such as the use of a shoaling coefficient with simple Airy wave theory, the linear models will underestimate shoaling
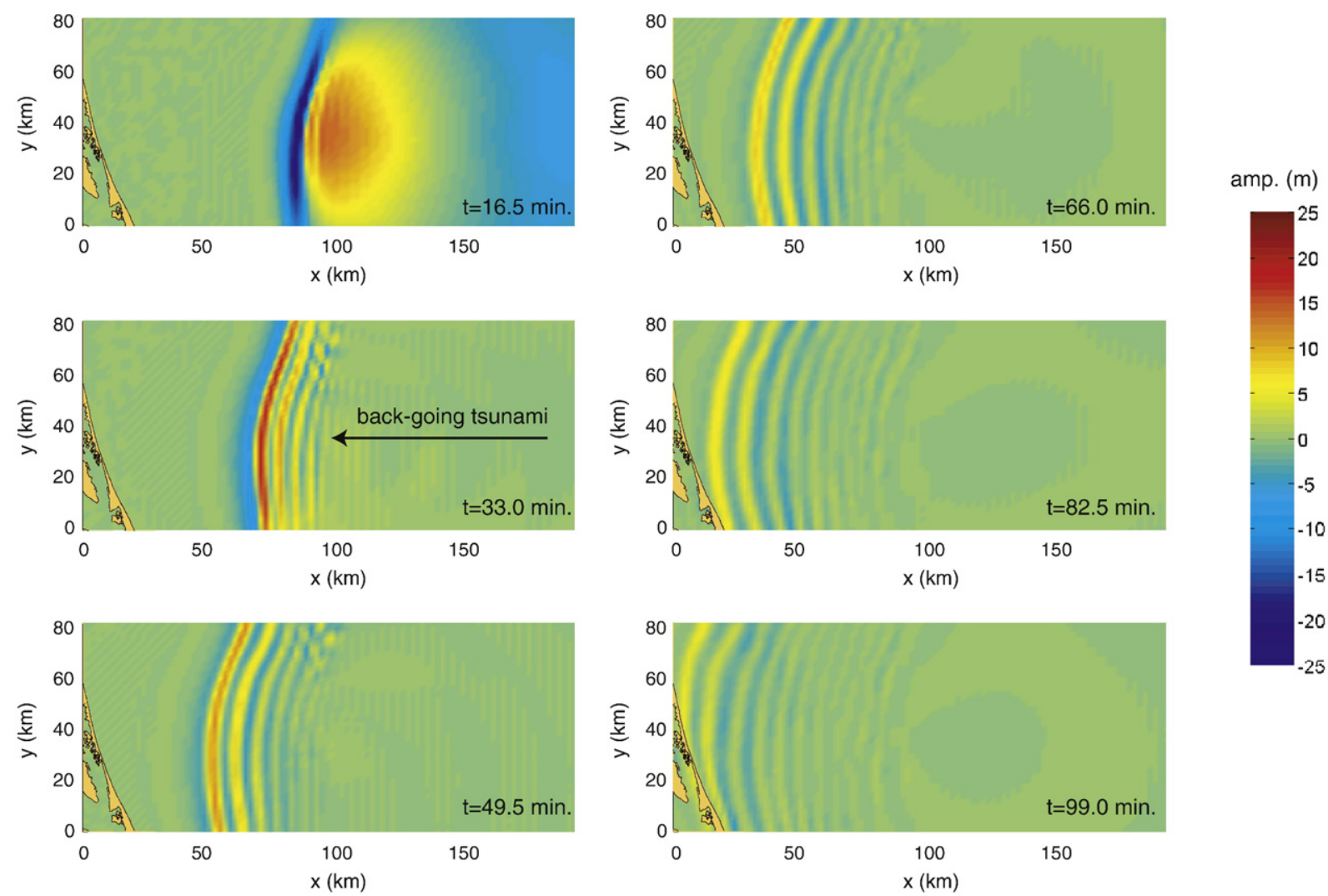

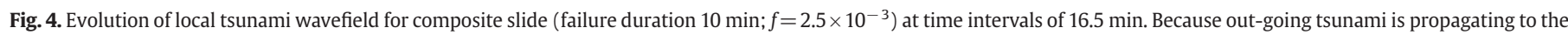
right at high speeds, primarily the back-going tsunami is shown as it propagates across the continental shelf. Location of model domain shown in Fig. 1. 
amplification. The linear theory also underestimates the maximum amplitude in the source region, consistent with results described by Lynett and Liu (2002). For the out-going wave in deep water (i.e., greater than $2 \mathrm{~km}$ water depth; right side Fig. 2), in contrast, there is little difference between the linear and nonlinear formulations. There is also little difference for this case study between the WNL-EXT and FNL-EXT formulations (Fig. 2), although nonlinearity becomes increasingly important in the nearshore region, as we will demonstrate.

\subsection{Tsunami generation}

The landslide source for tsunami waves is parameterized by its geometry and duration of vertical displacement (Lynett and Liu, 2002, 2005). A two-sided vertical displacement geometry (i.e., dipole) is used in this study to represent the regions of excavation and deposition (Fig. 3) (cf., Trifunac et al., 2002, 2003). The landslide kinematics are specified by a width of slope that fails, downslope lengths for the regions of excavation and deposition, and the maximum thickness of slide masses. Both the downslope and shore-parallel displacements are smooth functions to ensure numerical stability in the hydrodynamic calculations. Because tsunami generation is principally affected by vertical motion of the seafloor, the time history is parameterized by an overall duration of the vertical component of slide movement. Since our focus is the back-going wave propagating to the local shoreline (i.e., leading-depression phase; Fig. 4), this is interpreted as the duration of excavation during landslide movement termed "failure duration." The first elevation phase of the back-going wave is generated in the region of deposition. The out-going wave, propagating in the direction of slide movement, quickly moves out of this model domain (Fig. 4). The resulting volumes of the regions of excavation and deposition are approximately conserved.

\section{Results}

Potential tsunamis from the Currituck landslide are examined in four different sets of simulations. First, we calculate tsunami generation and propagation for three possible failure scenarios for the Currituck landslide derived from the stability and morphology analysis of Locat et al. (2009-this issue). Next, using each of the scenarios, we conduct a sensitivity analysis of two critical parameters for the local tsunami: duration of landslide failure and bottom friction of the continental shelf. The third simulation examines the regional propagation of the tsunami over a much larger area to determine whether significant energy propagates at oblique angles to the slide axis. The final simulation is a very high-resolution 1D propagation and runup model to accurately model dispersion, nonlinearity, and wave breaking as the tsunami propagates across the continental shelf and runs up onto the barrier islands broadside from the landslide.

\subsection{Currituck landslide scenarios}

The first tsunami simulations are computed for three landslide geometries discussed by Locat et al. (2009-this issue): Slide 1 (downslope sub-event, volume $=108 \mathrm{~km}^{3}$ ), Slide 2 (upslope subevent, volume $=57 \mathrm{~km}^{3}$ ), and a composite of Slides 1 and 2 (volume $=128-165 \mathrm{~km}^{3}$ ) (cf., Prior et al., 1986). Previously, it has

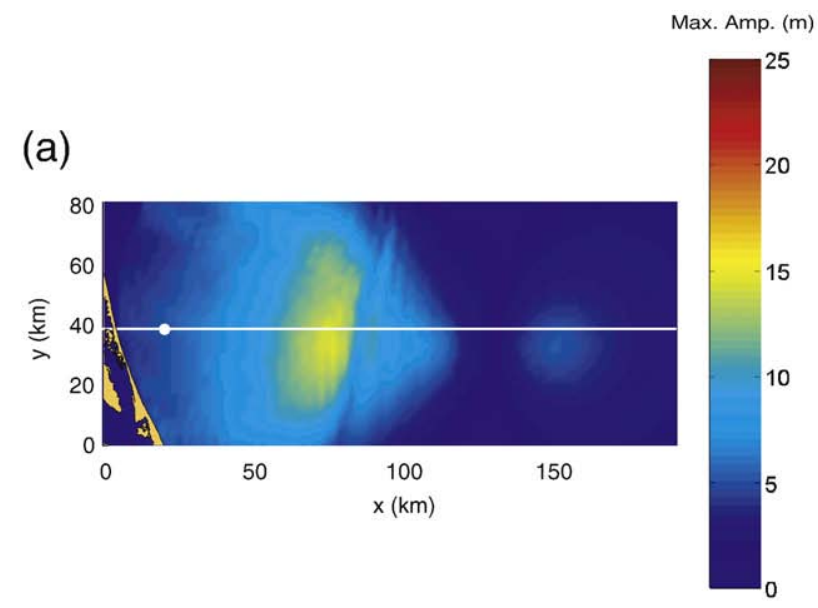

(b)

(c)
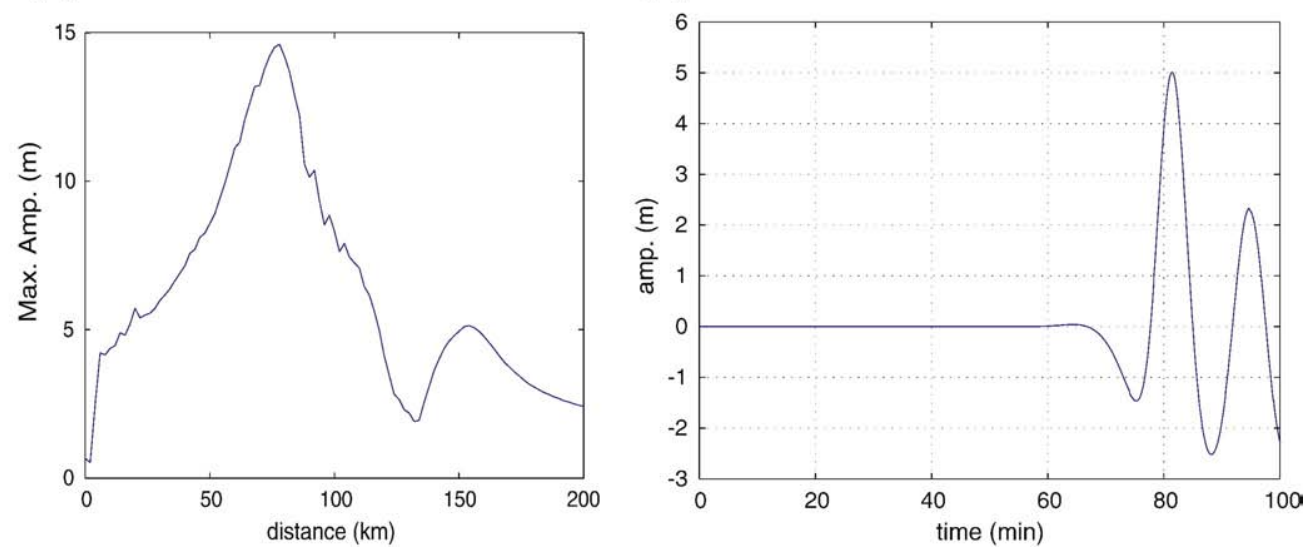

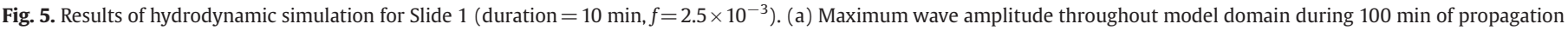

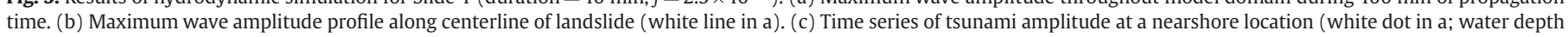
$22 \mathrm{~m}$ ) broadside (directly across) from the landslide. 
been unclear whether Slides 1 and 2 occurred as separate tsunamigenerating events (relative to the phase speed of tsunami waves), although Locat et al. (2009-this issue) suggest that the two sub-events occurred simultaneously during failure (i.e., the composite slide). Evolution of the tsunami wavefield is calculated for a propagation time of $100 \mathrm{~min}$, which is approximately the time it takes the first waves to reach the nearest shoreline (Currituck Banks) at the western edge of the model domain. Results are presented in the form of (1) maps of maximum wave amplitude throughout the model domain during the entire propagation time, (2) profiles of maximum wave amplitude along a transect aligned in the middle of the slide, and (3) time series of wave amplitude (marigram) at a nearshore location (20 km offshore) broadside from the landslide. For (3), the water depth for the nearshore location is $22 \mathrm{~m}$. Initial results for each slide scenario are described using a failure duration of $10 \mathrm{~min}$ and a bottom friction coefficient of $f=2.5 \times 10^{-3}$ that is typical for the continental shelf (Soulsby, 1983) (Table 1). Tsunami energy dissipation from bottom turbulence is primarily important for propagation across the shallow continental shelf. The effect of variations in each of these parameters is described in the next set of simulations (Section 3.2).

For Slide 1, the peak in tsunami amplitude is landward of the generation region and is caused by shoaling amplification of the backgoing wave from the source region to the continental shelf edge (Fig. 5a,b). Additional shoaling amplification from the continental shelf edge to shore is slight in comparison to attenuation of the tsunami from geometric spreading, bottom friction, and wave breaking. A secondary peak seaward of the source region is caused by the downslope directivity of the out-going tsunami. Significant off-axis tsunami energy for the back-going wave is evident in Fig. 5a that would affect coastal sites at azimuths oblique to the landslide (outside this model domain and discussed in Section 3.3 below). The initial drawdown of the tsunami at the nearshore station starts approximately $65 \mathrm{~min}$ after landslide initiation and lasts approximately $15 \mathrm{~min}$ before the initial elevation wave arrives (Fig. 5c).

The excavation area for Slide 2 is at shallow water depths and therefore the back-going tsunami is less affected by shoaling amplification compared to Slide 1 . Because of this and because the volume of Slide 2 is smaller than that for Slide 1, the peak amplitudes are significantly less (Fig. 6a,b). Note that the seaward peak in tsunami amplitude over the deposition region (Fig. 6a) is slightly off the center axis profiled in Fig. 6b. The drawdown at the nearshore station occurs slightly earlier for Slide 2 (Fig. 6c) compared to Slide 1 (Fig. 5c) but is otherwise similar.

For the composite scenario where Slide 1 and Slide 2 occur as a single tsunami generating event, the amplitudes near the source are much larger than for each individual slide (Fig. 7a,b). The nearshore tsunami amplitudes for the composite slide, are slightly less than for Slides 1 and 2 combined, owing to the dissipative effects of bottom friction during propagation. The initial drawdown phase for the composite slide is less pronounced (Fig. 7c) than for either Slide 1 or Slide 2.

\subsection{Effect of variations in failure duration and bottom friction}

For each slide scenario described above, three different values of failure duration in the excavation region are used to determine the effect on the tsunami wavefield (Table 1). In general, landslide duration is inversely proportional to the height of the generated tsunami waves, holding landslide volume constant. Two duration values are chosen

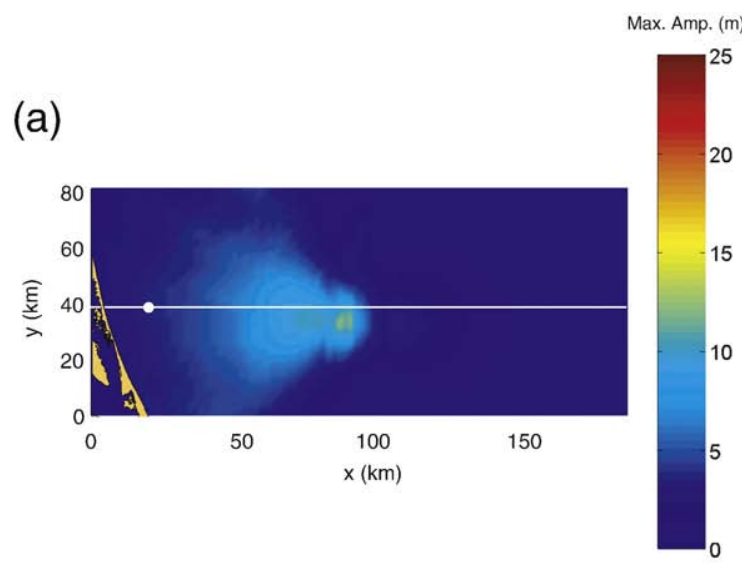

(b)

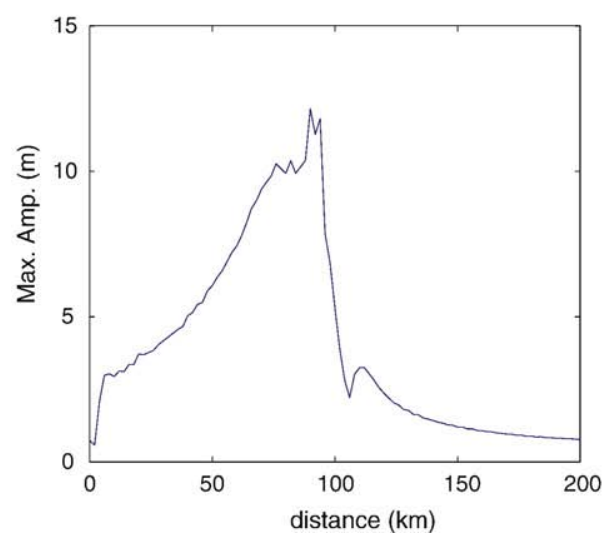

(c)

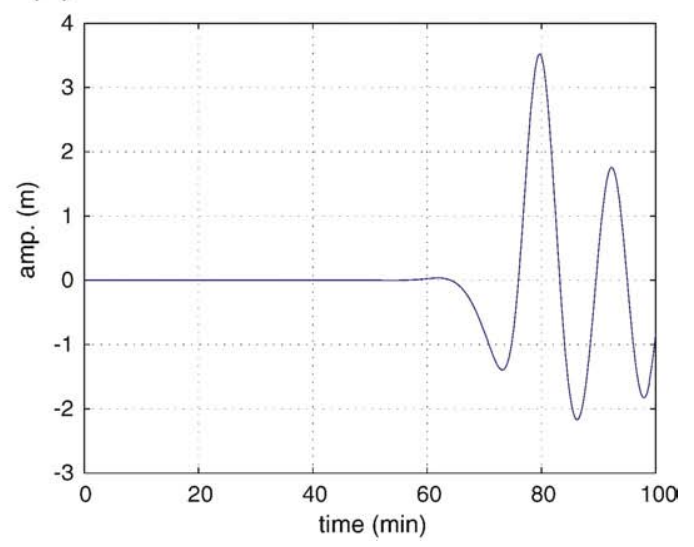

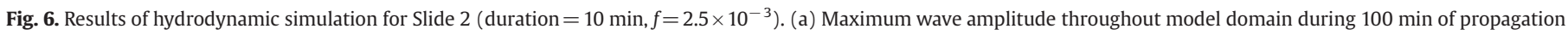

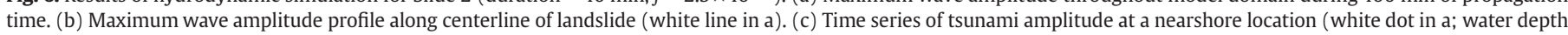
$22 \mathrm{~m}$ ) broadside (directly across) from the landslide. 
according to the characteristic times, dependent on acceleration and deceleration of the moving mass, from the mobility analysis of the Currituck landslide (Locat et al,, 2009-this issue). The first value is the time of the maximum in slide deceleration (approximately $10 \mathrm{~min}$ ). The second value is the time that acceleration approaches 0 after the deceleration phase starts (approximately $20 \mathrm{~min}$ ). It is thought that the former value better accounts for the initial high acceleration of failure, whereas the latter value represents the overall total duration of slide movement in the excavation region. We also examine a very short duration time ( $7.2 \mathrm{~min}$ ) to examine the effect on tsunami amplitudes of a slide that is much more mobile than expected from the post-failure analysis (e.g., from low basal shear stress, Elverhøi et al., 2005).

Results shown in Fig. 8 indicate that failure duration has a significant effect on maximum tsunami amplitudes over the source region (bottom friction held constant at $f=2.5 \times 10^{-3}$ ). Because tsunami waves leave the source region at a phase speed of $\sqrt{g h}$ (long wavelength limit), slower process times will result in smaller initial tsunami amplitudes, under subcritical conditions. This effect is also evident for the out-going tsunami (right side of model domain), which is significantly affected by downslope landslide speed (Todorovska et al., 2002; Trifunac et al., 2002).

Bottom friction is parameterized in COULWAVE by the friction coefficient $f$. Shear stress $(\tau)$ at the bottom boundary is given by

$\tau=\frac{1}{2} \rho f\left|\mathrm{u}_{\mathrm{b}}\right| \mathrm{u}_{\mathrm{b}}$

where $\rho$ is fluid density and $\mathbf{u}_{\mathrm{b}}$ is the horizontal velocity field near the sea floor. Increasing the bottom friction coefficient will lead to greater dissipation of tsunami energy during propagation. The friction coef- ficient is related to two other parameters that describe the hydraulic roughness of the bottom boundary layer: Chézy coefficient $(C)$ and Manning's roughness coefficient $(n)$

$$
\begin{aligned}
& f=\frac{g}{C^{2}} \\
& f=\frac{g n^{2}}{(h+a)^{1 / 3}}
\end{aligned}
$$

where $g$ is the gravitational acceleration, $h$ is the water depth and $a$ is the tsunami amplitude. Estimates of $f$ for continental shelf environments range between approximately $1.6-6.1 \times 10^{-3}$, depending on the bottom type and the presence of bed forms (Soulsby, 1983). In addition, estimates of $f$ for shoaling waves and runup are considerably higher: $f>10^{-2}$ (Mei, 1989; Satake, 1995).

Results of using different bottom friction coefficients for the composite slide scenario are shown in Fig. 9 (failure duration held constant at $10 \mathrm{~min}$ ). Above the source region, maximum tsunami amplitude decreases slightly with increasing friction coefficient. During propagation of the back-going tsunami across the continental shelf, however, higher bottom friction results in greater energy dissipation and significantly smaller tsunami amplitude estimates. Conversely, for the out-going tsunami, the effect is minimal because of the much greater water depths along the continental slope.

Bivariate analysis of the effect failure duration and bottom friction have on maximum nearshore tsunami wave height are presented for each of the slide scenarios in Fig. 10. In each case, bottom friction has more of an effect on maximum nearshore tsunami wave height than failure duration, for the ranges tested. The curvature in the contours of

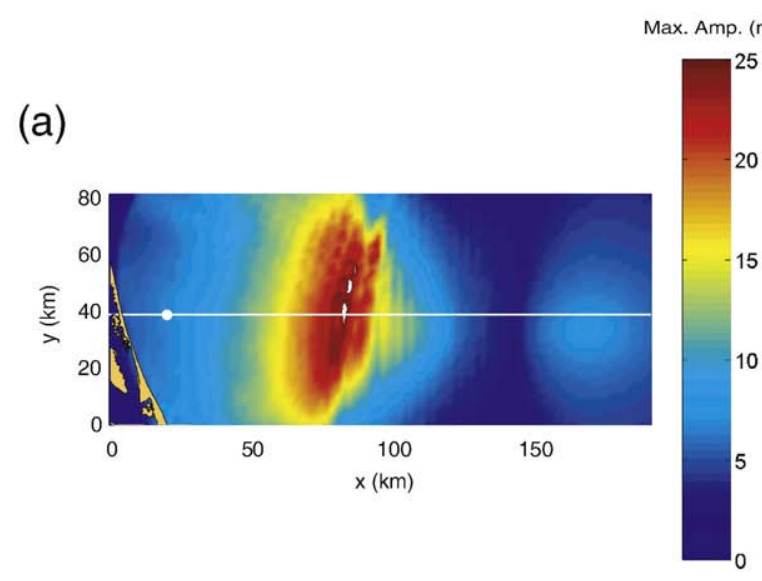

(b)

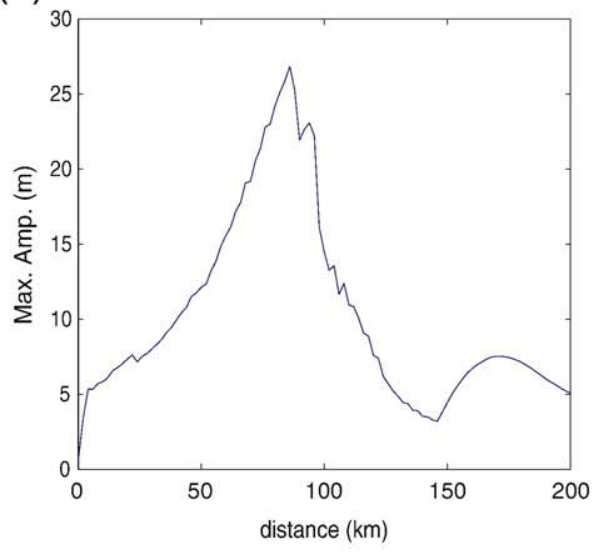

(c)

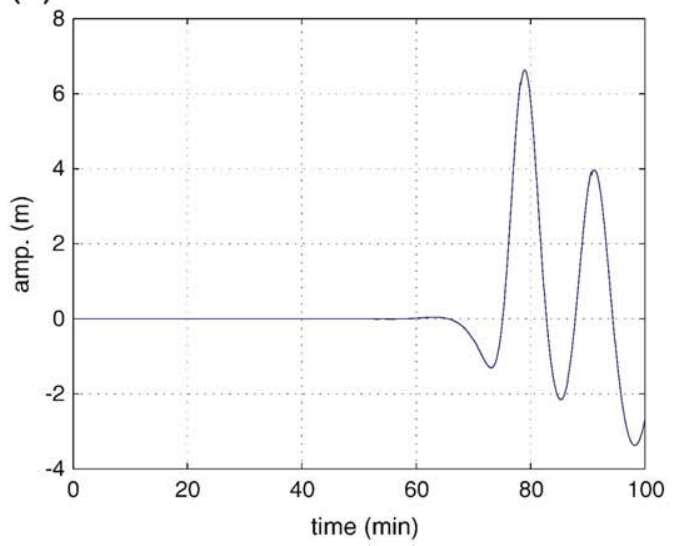

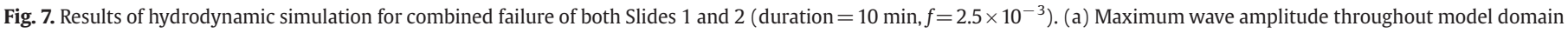

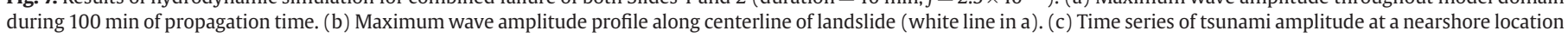
(white dot in a; water depth $22 \mathrm{~m}$ ) broadside (directly across) from the landslide. 

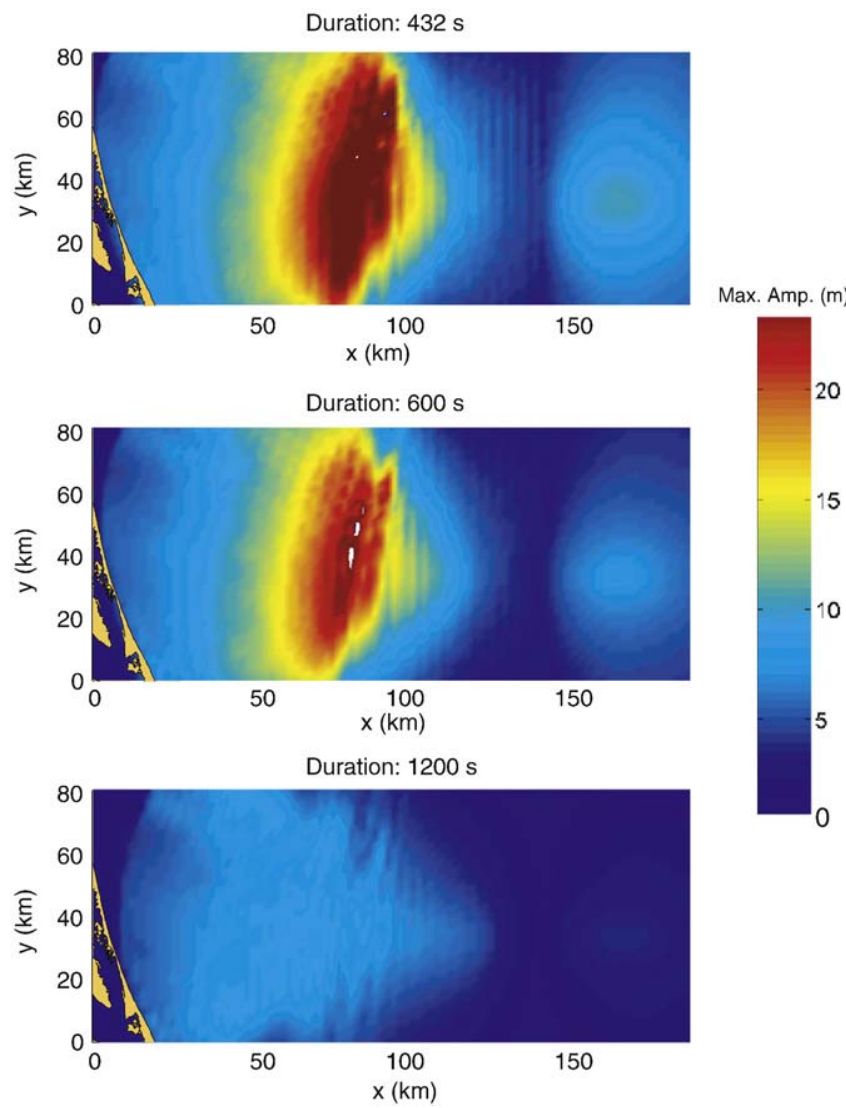

Fig. 8. Comparison of maximum wave amplitude maps for the composite slide scenario (Slide 1 and Slide 2 ) using different values for failure duration in the excavation region.
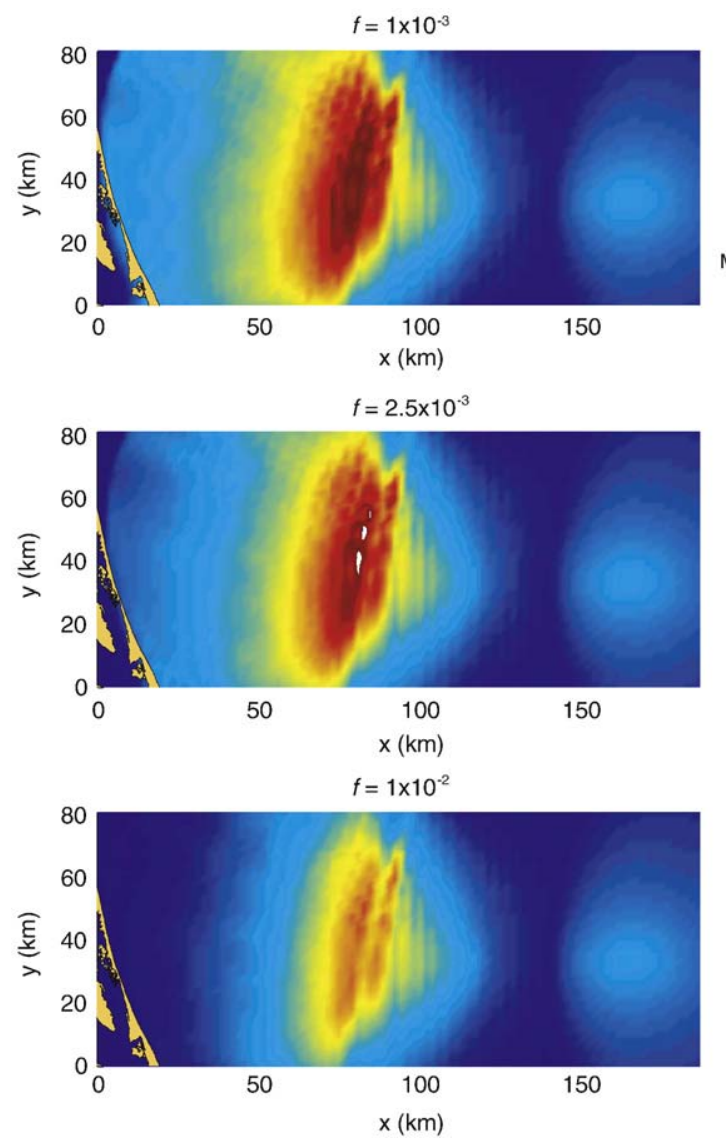

ax. Amp. (m)

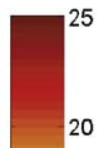

Fig. 9. Comparison of maximum wave amplitude maps for the composite slide scenario (Slide 1 and Slide 2) using different values for the bottom friction coefficient. maximum wave height indicates that failure duration is a more significant effect for low values of bottom friction $\left(f \sim 10^{-3}\right)$. For high values of bottom friction $\left(f \sim 10^{-2}\right)$, maximum nearshore wave height is less sensitive to variations in failure duration.

\subsection{Regional propagation}

We next examine the regional tsunami propagation pattern from the Currituck landslide using a much larger model domain. For this

(a) Maximum Nearshore Wave Height $(m)$ : Slide 1

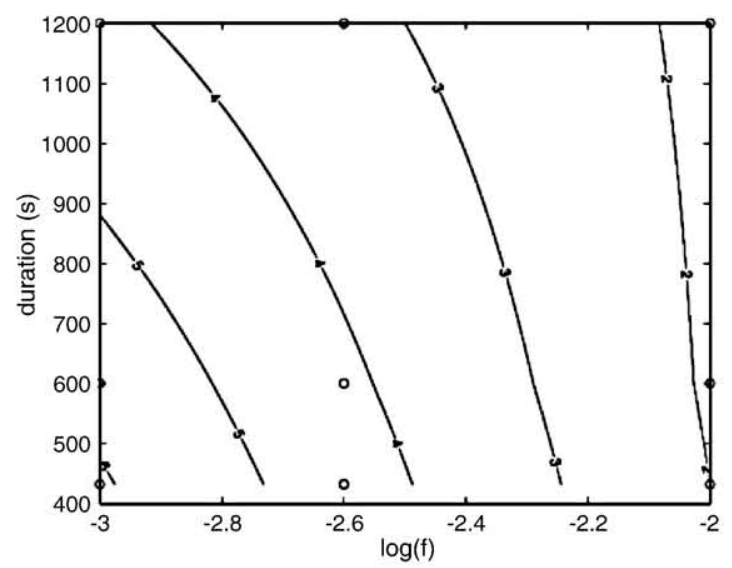

(b) Maximum Nearshore Wave Height (m): Slide 2

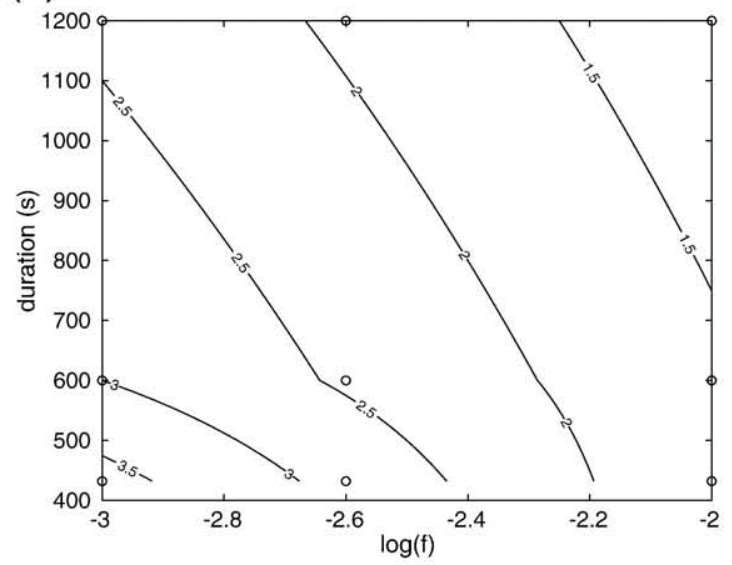

(C) Maximum Nearshore Wave Height $(\mathrm{m})$ : Slide $1+$ Slide 2

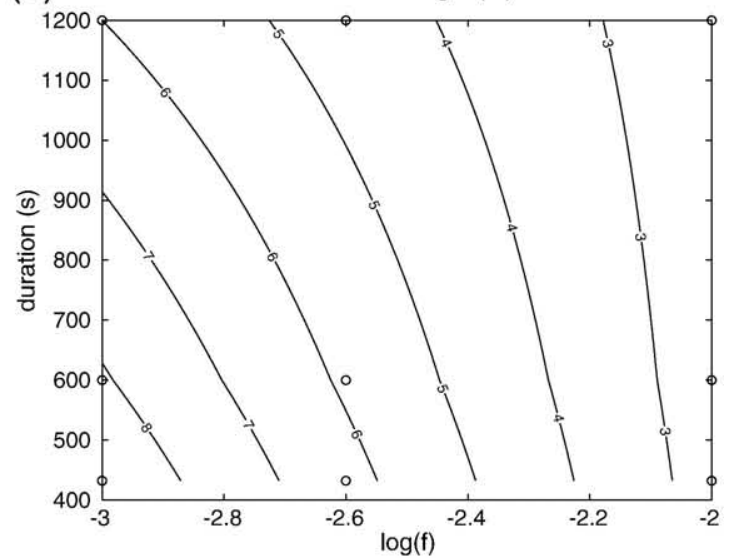

Fig. 10. Bivariate analysis of the effect failure duration and bottom friction have on nearshore tsunami wave amplitude for (a) Slide 1; (b) Slide 2; and (c) the composite slide. Water depth where maximum wave amplitude is sampled is $18 \mathrm{~m}$. Circles represent results from individual simulations. 
case, we use the scenario that produces the largest tsunami of the ones tested: the composite slide (Slide 1 plus Slide 2 ) and a failure duration of $7.2 \mathrm{~min}$. In addition to the broadside, back-going phase that was modeled in the previous simulation set, another phase becomes apparent in the regional model (Fig. 11). This phase originates in the region of deposition and is refracted toward the coast owing to the gradual northeastward bend in the trend of the continental slope. In contrast to the leading depression phase of the back-going tsunami that originated in the region of excavation, the refracted wave is characterized by a leading elevation phase. Thus, the leading phase of the two different waves propagating toward the coast have opposite polarities. This is analogous to the local tsunami generated from oblique fault slip that also produces a secondary tsunami phase of opposite polarity (Geist and Yoshioka, 1996; Geist, 1999). Although the refracted wave greatly increases the length of coastline affected by this tsunami, this may only apply for landslide locations near bends in the continental slope. Wave heights of the refracted wave along the more regional shorelines in this scenario are likely to be less than approximately $2 \mathrm{~m}$ and hence affect only the lowest lying regions.

\subsection{High-resolution $1 D$ modeling}

To determine the effect that nonlinearity and dispersion have on nearshore propagation and runup, a high-resolution 1D simulation was performed along a transect aligned with the center axis of the landslide (Fig. 12). To accurately model these effects it was determined that a grid spacing of $5 \mathrm{~m}$ and the fully nonlinear (FNLEXT) equations were needed. Energy dissipation from wave breaking is employed using an eddy viscosity scheme (Kennedy et al., 2000), though because this is a 1D simulation, the attenuating effect of geometric spreading is not included. Runup was computed at mean sea level, noting that the tidal stage at the time of a tsunami will also influence runup and inundation (Mofjeld et al., 2007). The bathy- metry was interpolated to this grid spacing from the regional DEM. Like the previous regional propagation model, the source for the 1D model is the composite slide with a 7.2 min failure duration.

Several interesting phenomena are evident in this simulation that were not evident in the coarse-grid, regional 2D simulations. First, prior to wave breaking, the wave front fissions into a train of shortwavelength waves ( $100-200 \mathrm{~m}$ in $30 \mathrm{~m}$ water depth). Wave fission is a separation process where wave energy, initially phase-locked to the primary wave or pulse, attains certain properties, such as higher or lower phase speed, that allow it to disconnect from the primary wave and propagate as a free wave. This process can sometimes lead to the formation of an undular bore (e.g., Glimsdal et al., 2007). For additional description of the fission process, as well as the numerical considerations that must be taken into account to properly simulate this phenomenon, see Lynett (2008). The short-period fission waves shown in Fig. 12 are very steep and nonlinear, individually break far offshore, and are sensitive to the bottom friction coefficient, due to their long duration of propagation (in terms of number of periods) over shallow water. The wave front breaks approximately $45 \mathrm{~km}$ offshore and forms a tsunami bore that continues to propagate shoreward (cf., Yeh, 1991). During runup, the tsunami overtops Currituck Banks and floods Currituck Sound, still as a breaking wave. Maximum runup is about $3 \mathrm{~m}$, although water surface elevations exceed 6 m near the shoreline. The fission waves do not appear to greatly influence runup. These short waves break offshore and transfer momentum into the bore, which is clearly the dominant feature during the inundation phase.

\section{Conclusions}

Simulations of potential waves generated from the Currituck landslide yield a wide range in estimated near-shore wave heights. The primary source parameters that affect near-shore wave heights
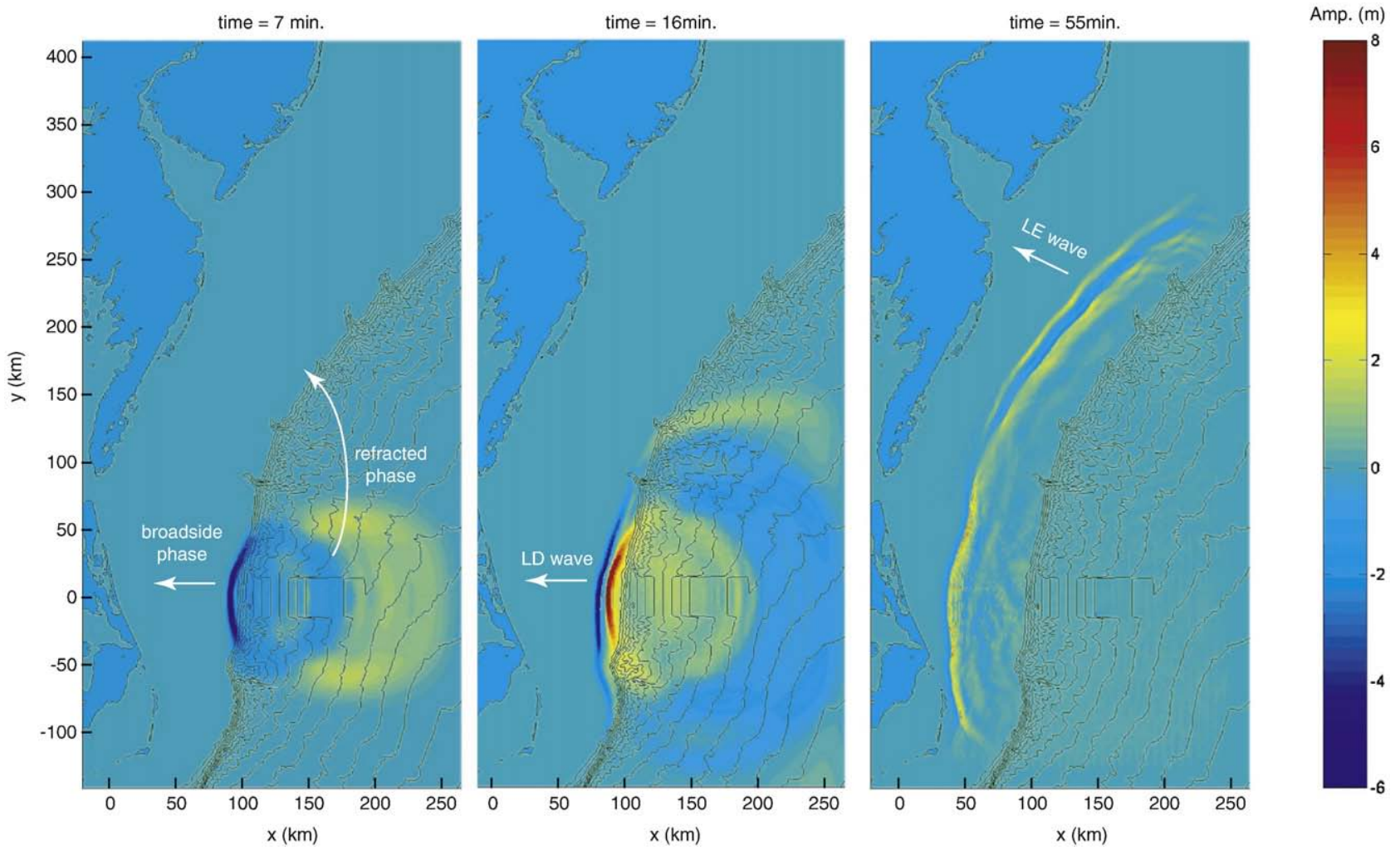

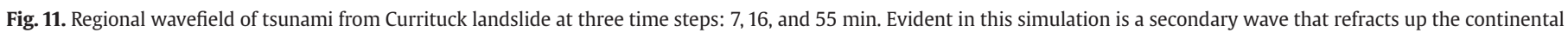
slope and toward shore north of the Currituck landslide. 
are the overall volume of the landslide and the initial acceleration and duration of vertical movement in the excavation region that generates the back-going, leading depression wave (cf., Murty, 2003; Harbitz et al., 2006). These results are consistent with an analogous study of the Storegga landslide by Løvholt et al. (2005). The mobility analysis, presented by Locat et al. (this volume), is key in constraining the failure duration parameter. Reasonable variations in failure duration have less of an effect on nearshore wave height estimates than the primary source parameter: landslide volume. Other source parameters of the landslide tsunami such as water depth in the excavation region, slide thickness, and downslope length also have a secondary effect on the wave characteristics. The primary hydrodynamic parameter that affects estimates of nearshore wave height is bottom friction along the continental shelf and nearshore region. Improvements to future models would incorporate different coefficients for bottom friction in the shelf and nearshore region. It is also shown that an assumption of linearity in the momentum equations overestimates the nearshore wave heights.

Potential tsunamis for the Currituck landslide are further explored using regional propagation models and high-resolution 1D models to simulate nearshore propagation and runup. Both of these models require substantial computational resources in comparison to the coarse-grid local propagation models used for the source sensitivity simulations. The regional propagation models indicate that the curvature in the trend of the continental slope refracts wave energy emanating from the landslide deposition region. This secondary wave propagates farther to the north and has the opposite leading phase polarity than the primary broadside wave emanating from the region of excavation. The high-resolution 1D simulation reveals the effect that wave breaking and combined influence of dispersion and nonlinearity (described by the Boussinesq equations) has on nearshore propagation and runup. Overall, this study demonstrates

(a)
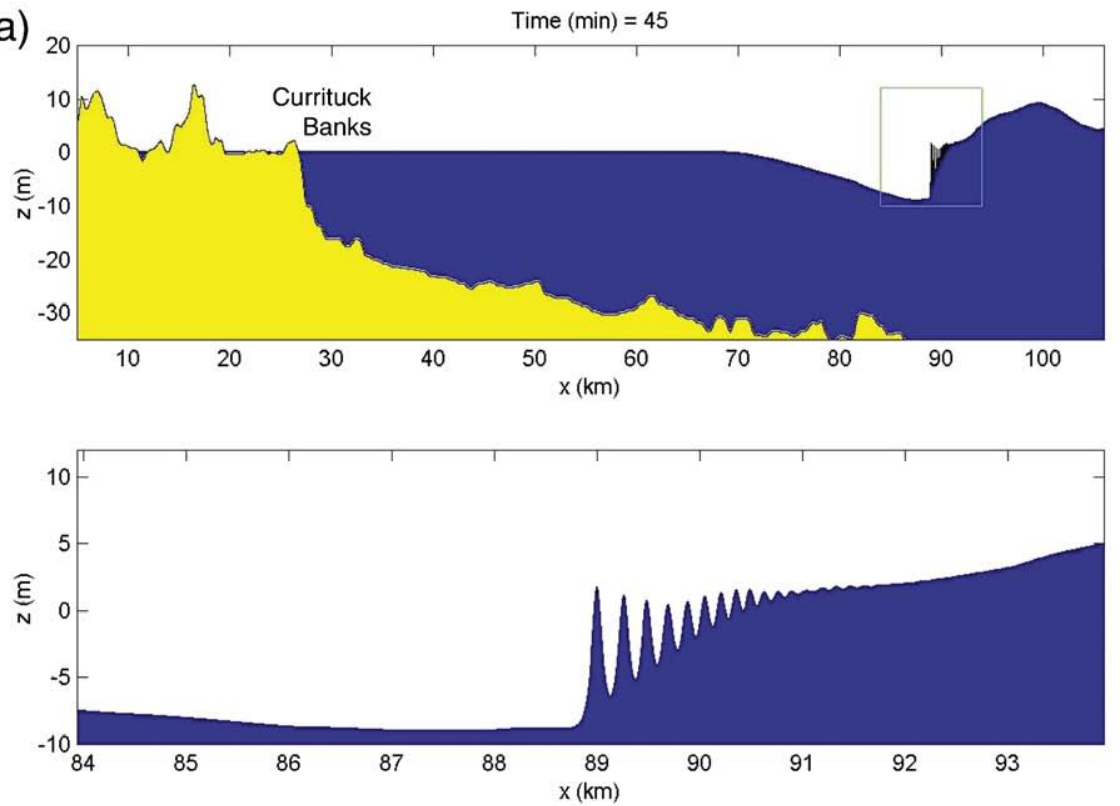

(b)
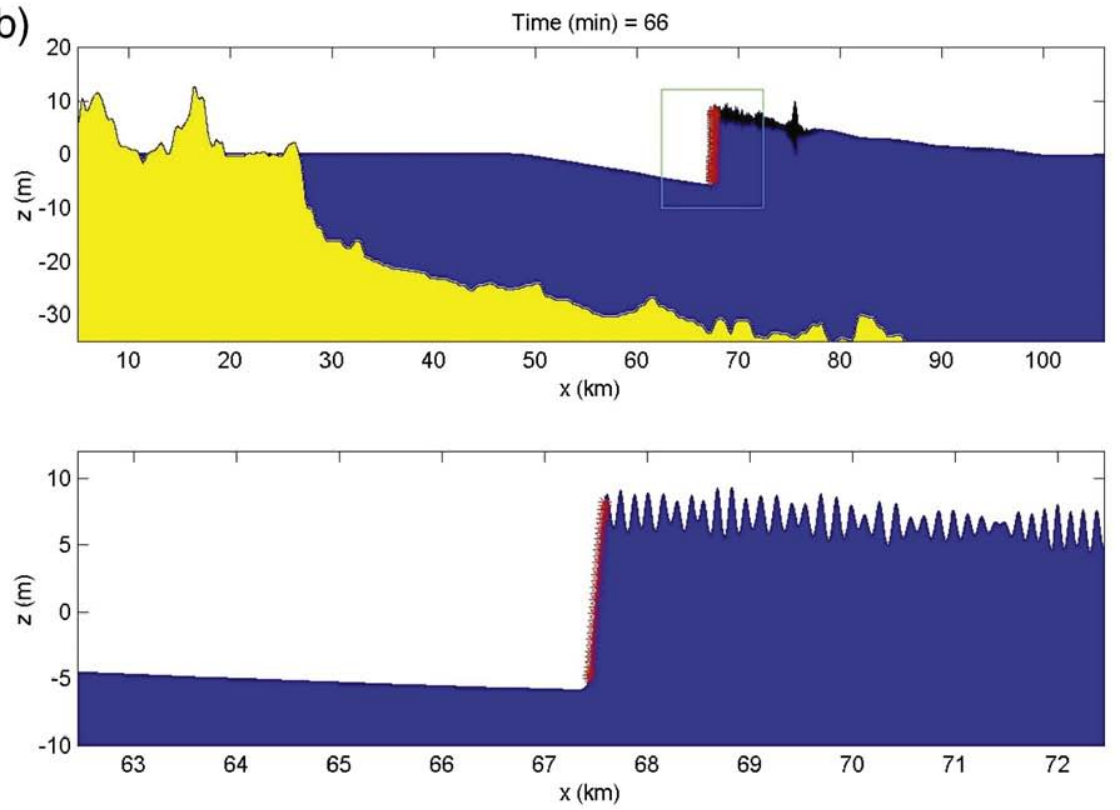

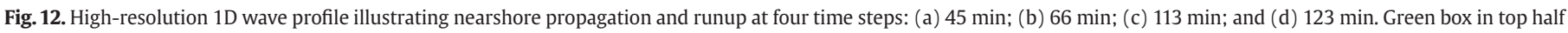
of each figure shows magnified area indicated in bottom half of figure. Red xs indicate wave breaking. 
(c)
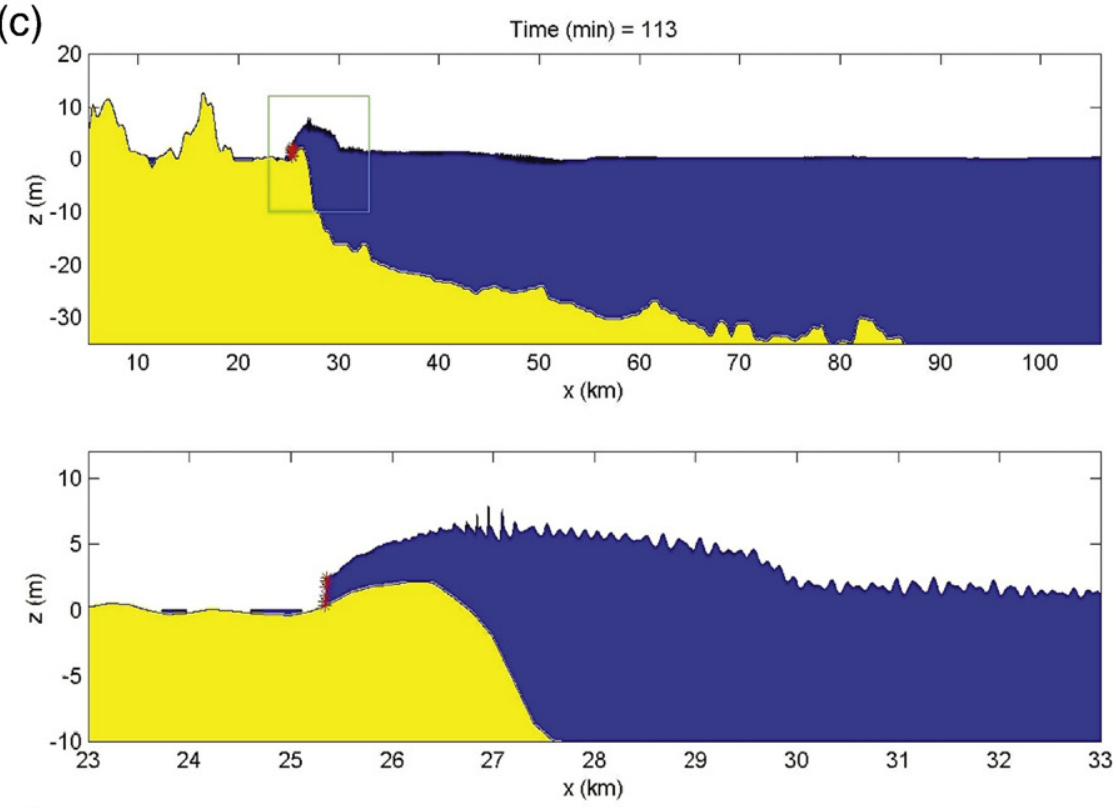

(d)
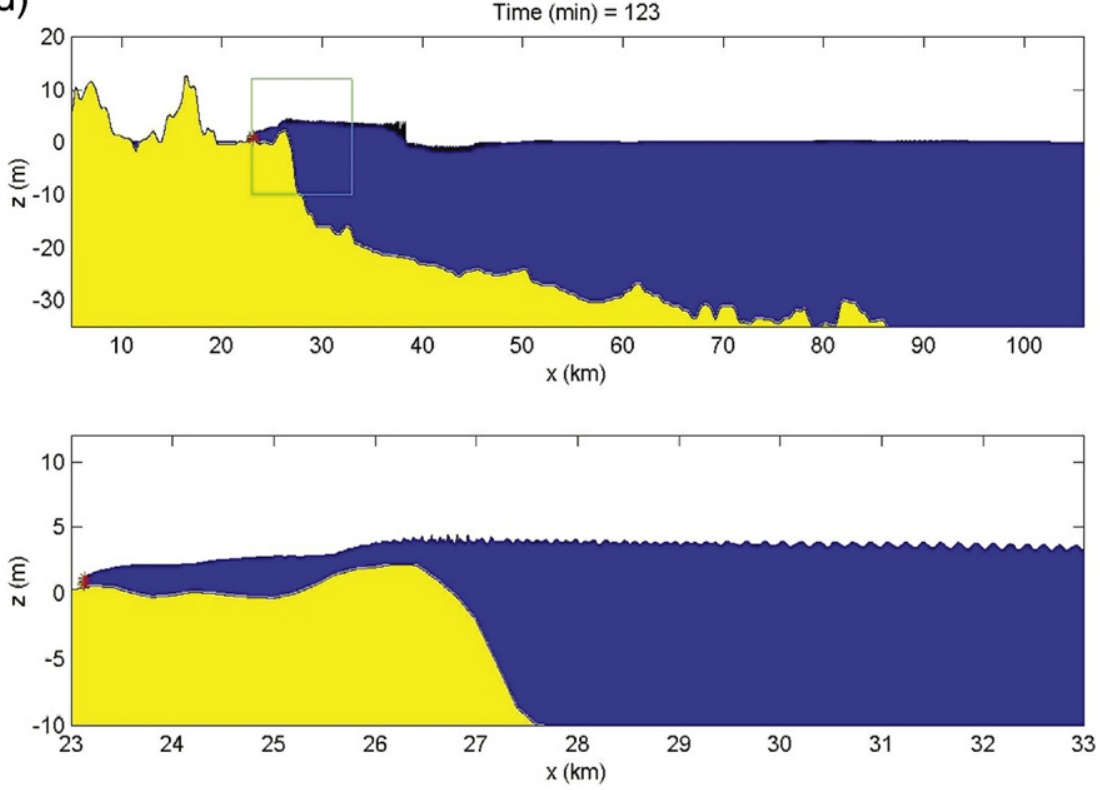

Fig. 12 (continued)

that landslide-generated tsunamis are highly complex phenomena and require multiple levels of investigation to accurately assess the hazard they pose to nearby and low-lying regional coastlines.

\section{Acknowledgements}

Research conducted by Lynett for this paper was partially supported by grants from the National Science Foundation (CBET0427014, CMMI-0619083). Discussions with Jingping Xu contributed to this paper. The authors thank Carl Harbitz, Carolyn Ruppel, Jacques Locat, and an anonymous reviewer for their constructive comments and Jane Ciener for editing the manuscript.

\section{References}

Caress, D.W., Chayes, D.N., 1996. Improved processing of Hydrosweep DS multibeam data on the R/V Maurice Ewing. Mar. Geophys. Res. 18, 631-650.

Carrier, G.F., 1971. The dynamics of tsunamis. In: Reid, W.H. (Ed.), Mathematical Problems in the Geophysical Sciences. Lectures in Applied Mathematics. American Mathematical Society, Providence, Rhode Island, pp. 157-187.
Chaytor, J.D., ten Brink, U.S., Solow, A.R., Andrews, B.D., 2009. Size distribution of submarine landslides along the U.S. Atlantic Margin. Mar. Geol. 264, 16-27 (this issue).

Chen, Y., Liu, P.L.-F., 1995. Modified Boussinesq equations and associated parabolic model for water wave propagation. J. Fluid Mech. 228, 351-381.

Elverhøi, A., et al., 2005. Emerging insights into the dynamics of submarine debris flows. Nat. Hazards Earth Syst. Sci. 5, 633-648.

Fine, I.V., Rabinovich, A.B., Bornhold, B.D., Thomson, R., Kulikov, E.A., 2005. The Grand Banks landslide-generated tsunami of November 18,1929: preliminary analysis and numerical modeling. Mar. Geol. 215, 45-57.

Gardner, J.V., Mayer, L.A., Armstrong, A.A., 2006. Mapping supports potential submission to U.N. Law of the Sea. Eos, Trans. Am. Geophys. Union 87, 157-159.

Geist, E.L., 1999. Local tsunamis and earthquake source parameters. Adv. Geophys. 39, 117-209.

Geist, E.L., Yoshioka, S., 1996. Source parameters controlling the generation and propagation of potential local tsunamis along the Cascadia margin. Nat. Hazards 13, 151-177.

Glimsdal, S., Pedersen, G.K., Langtangen, H.P., Shuvalov, V., Dypvik, H., 2007. Tsunami generation and propagation from the Mjølnir asteroid impact. Meteorit. Planet. Sci. $42,1473-1493$.

Harbitz, C.B., Løvholt, F., Pedersen, G., Masson, D.G., 2006. Mechanisms of tsunami generation by submarine landslides: a short review. Norw. J. Geol. 86, 255-264.

Haugen, K.B., Løvholt, F., Harbitz, C.B., 2005. Fundamental mechanisms for tsunami generation by submarine mass flows in idealised geometries. Mar. Pet. Geol. 22, 209-217. 
Imran, J., Parker, G., Locat, J., Lee, H., 2001. A 1-D numerical model of muddy subaqueous and subaerial debris flows. J. Hydraul. Eng. 127, 959-958.

Kennedy, A.B., Chen, Q., Kirby, J.T., Dalrymple, R.A., 2000. Boussinesq modeling of wave transformation, breaking and runup: I. one dimension. J. Waterw. Port Coast. Ocean Eng. 126, 39-47.

Korycansky, D.G., Lynett, P.J., 2005. Offshore breaking of impact tsunami: The Van Dorn effect revisited. Geophys. Res. Lett. 32. doi:10.1029/2004GL021918.

Korycansky, D.G., Lynett, P.J., 2007. Run-up from impact tsunami. Geophys. J. Int. 170, 1076-1088.

Lastras, G., De Blasio, F.V., Canals, M., Elverhøi, A., 2005. Conceptual and numerical modeling of the BIG'95 debris flow, western Mediterranean Sea. J. Sediment. Res. 75, 784-797.

Lee, H.J., 2009. Timing of occurrence of large submarine landslides on the Atlantic ocean margin. Mar. Geol. 264, 53-64 (this issue).

Locat, J., Lee, H., ten Brink, U.S., Twichell, D., Geist, E., Sansoucy, M., 2009 Geomorphology, stability and mobility of the Currituck slide. Mar. Geol. 264, 28-40 (this issue).

Løvholt, F., Harbitz, C., Haugen, K.B., 2005. A parametric study of tsunami generated by submarine slides in the Ormen Lange/Storegga area off western Norway. Mar. Pet. Geol. 22, 219-231.

Lynett, P.J., 2006. Nearshore wave modeling with high-order Boussinesq-type equations. Journal of the Waterways and Harbors Division, A.S.C.E. 132: 348-357.

Lynett, P., 2008. Modeling of tsunami inundation. In: Lee, W.H.K. (Ed.), Encyclopedia of Complexity and System Science. Springer-Verlag.

Lynett, P., Liu, P.L.F., 2002. A numerical study of submarine-landslide-generated waves and run-up. Proc. R. Soc. Lond., A 458, 2885-2910.

Lynett, P.J., Liu, P.L.-F., 2005. A numerical study of run-up generated by threedimensional landslides. J. Geophys. Res. 10. doi:10.1029/2004JC002443.

Lynett, P.J., Wu, T.-R., Liu, P.L.-F., 2002. Modeling wave runup with depth-integrated equations. Coast. Eng. 46, 89-107.

Mei, C.C., 1989. The Applied Dynamics of Ocean Surface Waves. Advanced Series on Ocean Engineering, vol. 1. World Scientific, Singapore. 740 pp.

Mofjeld, H.O., González, F.I., Titov, V.V., Venturato, A.J., Newman, A.V., 2007. Effects of tides on maximum tsunami wave heights: probability distributions. J. Atmos. Ocean. Technol. 24, 117-123.
Murty, T.S., 2003. Tsunami wave height dependence on landslide volume. Pure Appl. Geophys. 1160, 2147-2153.

Nwogu, O., 1993. Alternative form of Boussinesq equations for nearshore wave propagation. J. Waterw. Port Coast. Ocean Eng. 119, 618-638.

Okal, E.A., Synolakis, C.E., 2004. Source discriminants for near-field tsunamis. Geophys. J. Int. 158, 899-912.

Prior, D.B., Doyle, E.H., Neurauter, T., 1986. The Currituck Slide, Mid-Atlantic continenta slope; revisited. Mar. Geol. 73, 25-45.

Satake, K., 1995. Linear and nonlinear computations of the 1992 Nicaragua earthquake tsunami. Pure Appl. Geophys. 144, 455-470.

Shibata, M., 1983. One-dimensional dispersive deformation of tsunami with typical initial profiles on continental topographies. In: Iida, K., Iwasaki, T. (Eds.), Tsunamis: Their Science and Engineering. Terra Science Publication Company, Tokyo, pp. 241-250.

Soulsby, R.L., 1983. The bottom boundary layer of shelf seas. In: Johns, B. (Ed.), Physical Oceanography of Coastal and Shelf Seas. Elsevier, Amsterdam, pp. 189-266.

Todorovska, M.I., Hayir, A., Trifunac, M.D., 2002. A note on tsunami amplitudes above submarine slides and slumps. Soil Dyn. Earthqu. Eng. 22, 129-141.

Trifunac, M.D., Todorovska, M.I., 2002. A note on differences in tsunami source parameters for submarine slides and earthquakes. Soil Dyn. Earthqu. Eng. 22, 143-155.

Trifunac, M.D., Hayir, A., Todorovska, M.I., 2002. A note on the effects of nonuniform spreading velocity of submarine slumps and slides on the near-field tsunami amplitudes. Soil Dyn. Earthqu. Eng. 22, 167-180.

Trifunac, M.D., Hayir, A., Todorovska, M.I., 2003. A note on tsunami caused by submarine slides and slumps spreading in one dimension with nonuniform displacement amplitudes. Soil Dyn. Earthqu. Eng. 23, 223-234.

Twichell, D., Chaytor, J.D., ten Brink, U.S., Buczkowski, B., 2009. Morphology of late Quaternary submarine landslides along the U.S. Atlantic continental margin. Mar. Geol. 264, 4-15 (this issue).

Ward, S.N., 2001. Landslide tsunami. J. Geophys. Res. 106, 11,201-11,215.

Wei, G., Kirby, J.T., Grilli, S.T., Subramanya, R., 1995. A fully nonlinear Boussinesq mode for surface waves. Part 1. Highly nonlinear unsteady waves. J. Fluid Mech. 294 71-92.

Yeh, H.H., 1991. Tsunami bore runup. Nat. Hazards 4, 209-220. 